\title{
The International Day of Light in Spain: a three years perspective
}

\author{
Ignacio Moreno, María Yzuel, María Calvo
}

Ignacio Moreno, María J. Yzuel, María L. Calvo, "The International Day of Light in Spain: a three years perspective," Proc. SPIE 11480, Optics

Education and Outreach VI, 114800H (21 August 2020); doi: $10.1117 / 12.2567791$

SPIE. Event: SPIE Optical Engineering + Applications, 2020, Online Only 


\title{
The International Day of Light in Spain - a three years perspective
}

\author{
Ignacio Moreno *a,b, María J. Yzuel ${ }^{* *, c}$, María L. Calvo*,d \\ anstituto de Bioingeniería, Universidad Miguel Hernández de Elche, 03202 Spain \\ ${ }^{b}$ Dept. C. Materiales, Óptica y Tec. Electrónica, Univ. Miguel Hernández de Elche, 03202 Spain \\ 'Dept. Física, Universitat Autònoma de Barcelona, 08193 Bellaterra, Spain \\ ${ }^{\mathrm{d} D e p t}$ Óptica, Universidad Complutense de Madrid, 28040 Madrid, Spain
}

\begin{abstract}
In this article we report on the activities in Spain related to the celebration of the International Day of Light (IDL). The Spanish Committee for the IDL was constituted in 2017, as a continuation of the previous Committee for the International Year of Light (2015). This Committee involves different academic, scientific and industrial partners in Spain related to light science and light technologies, and develops actions to promote and disseminate the IDL activities. After the success of the 2018 and 2019 editions, the 2020 IDL celebration has been totally affected by the Covid-19 pandemic, and most of the programmed events were cancelled. Nevertheless, some on-line activities were developed. The aim of this work is to review the IDL impact in Spain in these last three years.
\end{abstract}

Keywords: International Day of Light, Outreach, Optics \& Photonics.

\section{INTRODUCTION}

After the success of the International Year of Light (IYL) in 2015, the Spanish related scientific community perceived very well the importance of the subsequent International Day of Light (IDL) initiative. Indeed, in 2014, a Spanish Committee for the IYL (2015) was constituted and, since its inception, was very active and a key for the success of the event in Spain. Therefore, right after the initiative of the subsequent IDL was announced, this Committee was reactivated and renewed as the new Spanish Committee for the International Day of Light, and formally created in 2017.

According to the goals of the IDL proclamation [1], the associated activities are intended to enable global appreciation of the central role that light and light-based technologies play in the lives of the citizens of the world in areas of science, medicine, communications, technology, culture, education, sustainable development and embedded technologies in our daily life. Also, they were intended to emphasize the importance of basic research in the fundamental science of light, the need for investment in light-based technology to develop new applications and improvements, the need to encourage professional careers in science and engineering in these fields and to attract students for science and engineering degrees by promoting activities for primary and secondary schools' students.

The Spanish Committee follows these similar goals and promotes and coordinates the individual efforts. One of the first steps was to create a specific website [2] and the related social media that recall the information of the IDL events in Spain. Another action was to promote the IDL among the related community, and some papers introducing the IDL were published in the Spanish scientific journals as in Revista Española de Física [3] and Optica Pura y Aplicada [4].

The year 2020 has been the third celebration of the International Day of Light (IDL), and a number of activities were programmed. After two consecutive years of celebration, 2018 and 2019, respectively [5,6], some of these activities are now becoming well-stablished every year. In particular, the celebration of an IDL flagship event. After the successful events held in Universidad Complutense de Madrid in 2018, and in Universidade de Santiago de Compostela in 2019, the 2020 edition had been programmed to be organized at the Faculty of Optics and Optometry of the Universitat Politècnica de Catalunya (UPC), in Terrassa (Barcelona). However, this and other programmed events had to be cancelled due to the Covid-19 pandemic. They have been postponed and hopefully they will be celebrated in May 2021. The situation forced the 2020 IDL celebration to become an on-line event.

** maria.yzuel@uab.cat; María J. Yzuel is President of the Spanish Committee of IDL

* 1.moreno@umh.es, mlcalvo@fis.ucm.es; Ignacio Moreno and Maria Luisa Calvo are Vice-Presidents of the Spanish Committee of IDL

Optics Education and Outreach VI, edited by G. Groot Gregory, Anne-Sophie Poulin-Girard,

Proc. of SPIE Vol. $11480114800 \mathrm{H} \cdot$ (c) 2020 SPIE · CCC code:

0277-786X/20/\$21 - doi: $10.1117 / 12.2567791$

Proc. of SPIE Vol. $11480114800 \mathrm{H}-1$ 
This paper reviews these efforts and activities of the Spanish Committee for the IDL and outlines the perspectives for the next year.

\section{COLLABORATORS OF THE IDL IN SPAIN}

To accomplish its goals, the Spanish Committee for the IDL counts with the support of a good number of national and international collaborators and sponsors. Figure 1 shows the corresponding logos of these organizations supporting the Spanish Committee for the IDL in 2020. These include collaborator organizations, which have representative members in the Committee and are directly involved in the realization of IDL events. They are scientific societies, like SEDOPTICA - The Spanish Society of Optics, and RSEF - the Royal Spanish Society of Physics, research and educational centers like UNED - the National Distance Education University, IO-CSIC, the Institute of Optics of the National Research Council, ICFO-the Institute of Photonic Sciences, ALBA Synchrotron, CD6-UPC the Centre for Sensors, Instruments and Systems Development, and industrial clusters and platforms like secpho, the Southern European Cluster in Photonics, Fotónica21, the Spanish mirror platform of the European platform Photonics21, APDI, the Association of Professionals in Illumination, and CEI, the Spanish Committee of Illumination.

Other organizations are involved as well supporting the realization of the Central flagship event. This year this central event was planned to take place at the Faculty of Optics and Optometry (FOOT) of the Universitat Politècnica de Catalunya, located in the city of Terrassa (Barcelona). Thus, some local institutions had already committed to support and participate in the event, like COOOC - the College of Opticians and Optometrists of Catalonia, the Museum of Science and Technique of Catalonia, located in Terrassa, and the Terrassa city council.

SPIE is also supporting some of the activities parallel to the flagship event, like the realization of demonstrations for secondary school students, and activities to promote the visibility of women in Optics.

The role of industry is also very important, and the Spanish Committee of the IDL is committed to enroll companies in the IDL celebration. Some companies like IOT - Indizen Optical Technologues, LASING, MTB and AEInnova had already participated with a direct support and involvement.

Unfortunately, in March 2020 all the work in progress was forced to stop due to the lockdown caused by the Covid-19 pandemic, and consequently causing an unavoidable cancellation of the event. Nevertheless, the Spanish Committee of the IDL, in agreement with the local organizers at FOOT, has already designated again Terrassa the place where the IDL flagship event will take place in 2021. Hopefully all the work that had been done will be useful and the planned event will be merely delayed by one year.

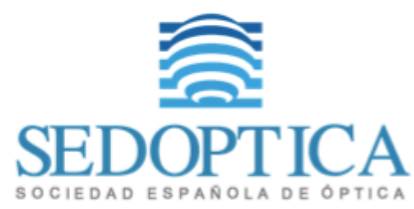

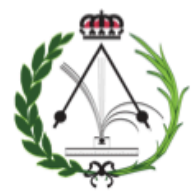

R.S.E.F.
Real Sociedad Española de Física

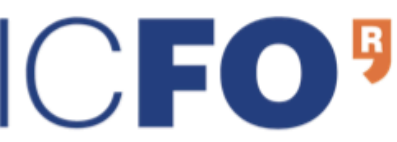

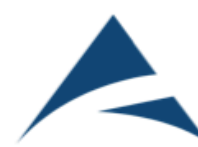

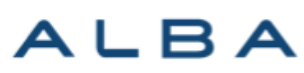

secpho

collaborate to innovate

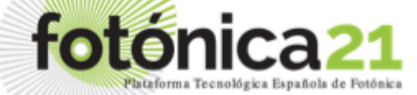

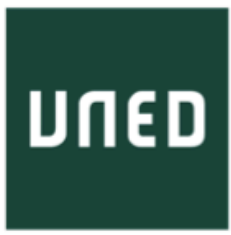
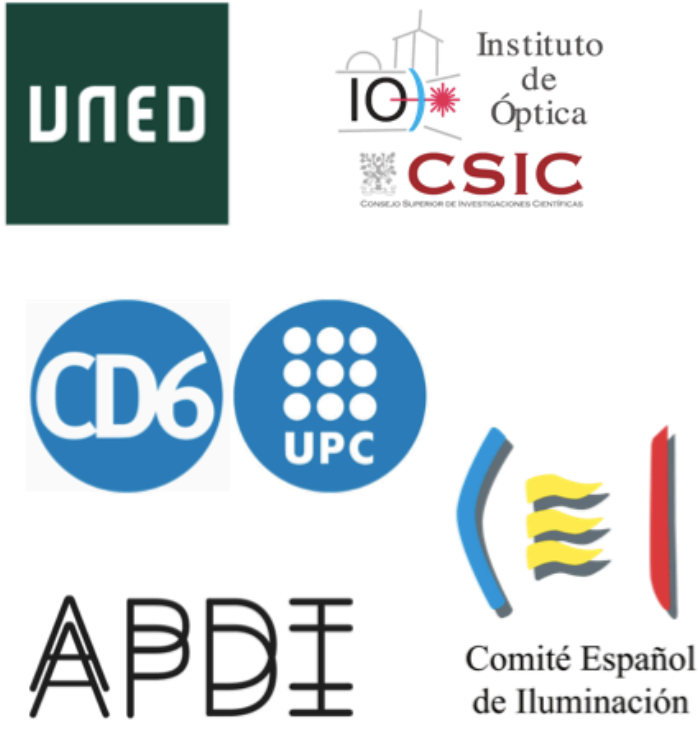

Comité Español de Iluminación

Fig. 1. Organizations collaborators participating in the Spanish Committee for the IDL 


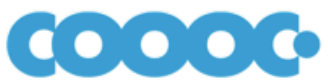

Col-legi Oficial d'Òptics Optometristes de Catalunya
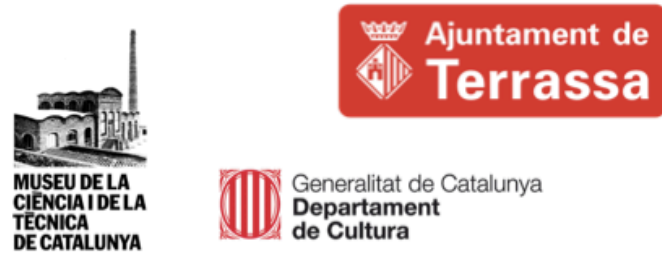

7II Generalitat de Catalunya Departament de Cultura
UNIVERSITAT POLITÈCNICA

DE CATALUNYA

BARCELONATECH

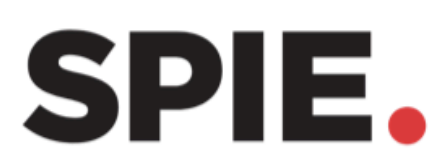

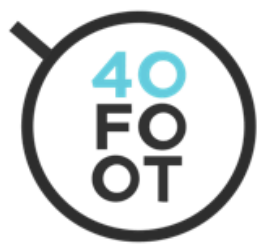

AElnnova

Alternative

Energy Innovations

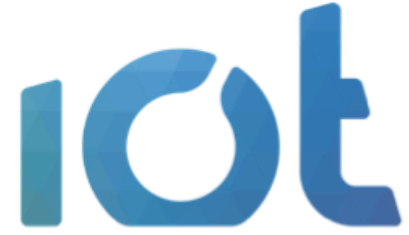

YOUR PARTNER IN LENS INNOVATION

"2L-ASSING

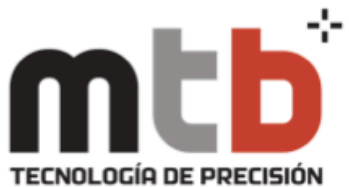

Fig. 2. Organizations supporting the 2020-21 flagship event of the IDL in Spain and sponsoring the Spanish Committee for the IDL.

\section{THE CENTRAL FLAGSHIP EVENTS OF THE IDL IN SPAIN}

A major central flagship event for the IDL has been organized every year in Spain. The first one, in 2018, was organized at the Faculty of Physics of the Universidad Complutense de Madrid (UCM) [5]. The second one, in 2019, was organized at Universidade de Santiago de Compostela (USC) [6]. These events are becoming well-stablished ones for the Optics \& Photonics community in Spain. Figure 3 shows some pictures at the end of the events in Madrid (left) and in Santiago de Compostela (right). Both events included several conferences by relevant invited speakers as well as other parallel activities like exhibitions, demonstrations for students and others. A detailed description can be found in $[5,6]$, and the talks are available online at $[7,8]$ respectively.
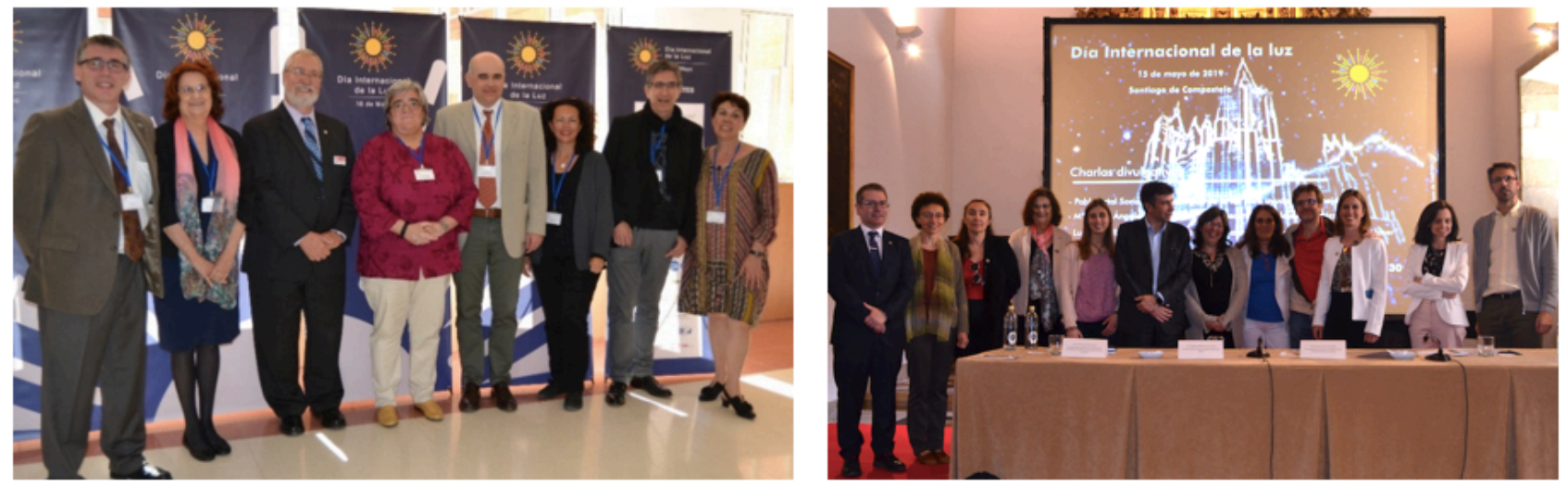

Figure 3. Pictures of some of the organizers and participants at the Central Flagship Event in Spain of the IDL in 2018 (left) organized at Universidad Complutense de Madrid and in 2019 (right) at Universidade de Santiago de Compostela.

The flagship 2020 Central IDL Event in Spain was programmed in the city of Terrassa, organized by the Faculty of Optics and Optometry of Terrassa (FOOT). The organizers of this event, chaired by Dr. Elisabet Pérez, wanted to give special emphasis to Light, Vision and Visual Health, taking advantage of the fact that the year 2020 coincides with the nomenclature 20/20, which is commonly used to designate normal visual acuity in common eye examinations. Figure 4 (left) shows the announcement of the event that had been distributed through all our channels and social networks. 
As the flagship event organized for May 2020 was cancelled, the local organization organized a photo contest between May $10^{\text {th }}$ and $20^{\text {th }}$ through Instagram. Various entities, companies and researchers (SEDOPTICA and its youth area, COOOC, IOT, María L. Calvo, FOOT, Secpho, Ajuntament de Terrassa, Fotónica21 and other collaborators of the DIL) greatly contributed to spreading the event through their social networks. Other related initiatives took place like that of the ALBA Synchrotron, publishing images related to "the lights of the Synchrotron" (@alba_synchrotron) during the days of the competition and also the OSA chapter of the Institute of Optics of Madrid (@iosa chapter) who shared images related to light throughout the day May $16^{\text {th }}$. The response was very positive, receiving almost 300 photos tagged with \#dil2020terrassa during the days of participation and gathering almost 200 new followers on the Instagram account (@DIL20_21Terrassa). Very diverse photographs participated light being as a common motif in all of them. The winner was Ginger Candelario (@gingercabu)with the picture shown in Fig. 4 (top right).

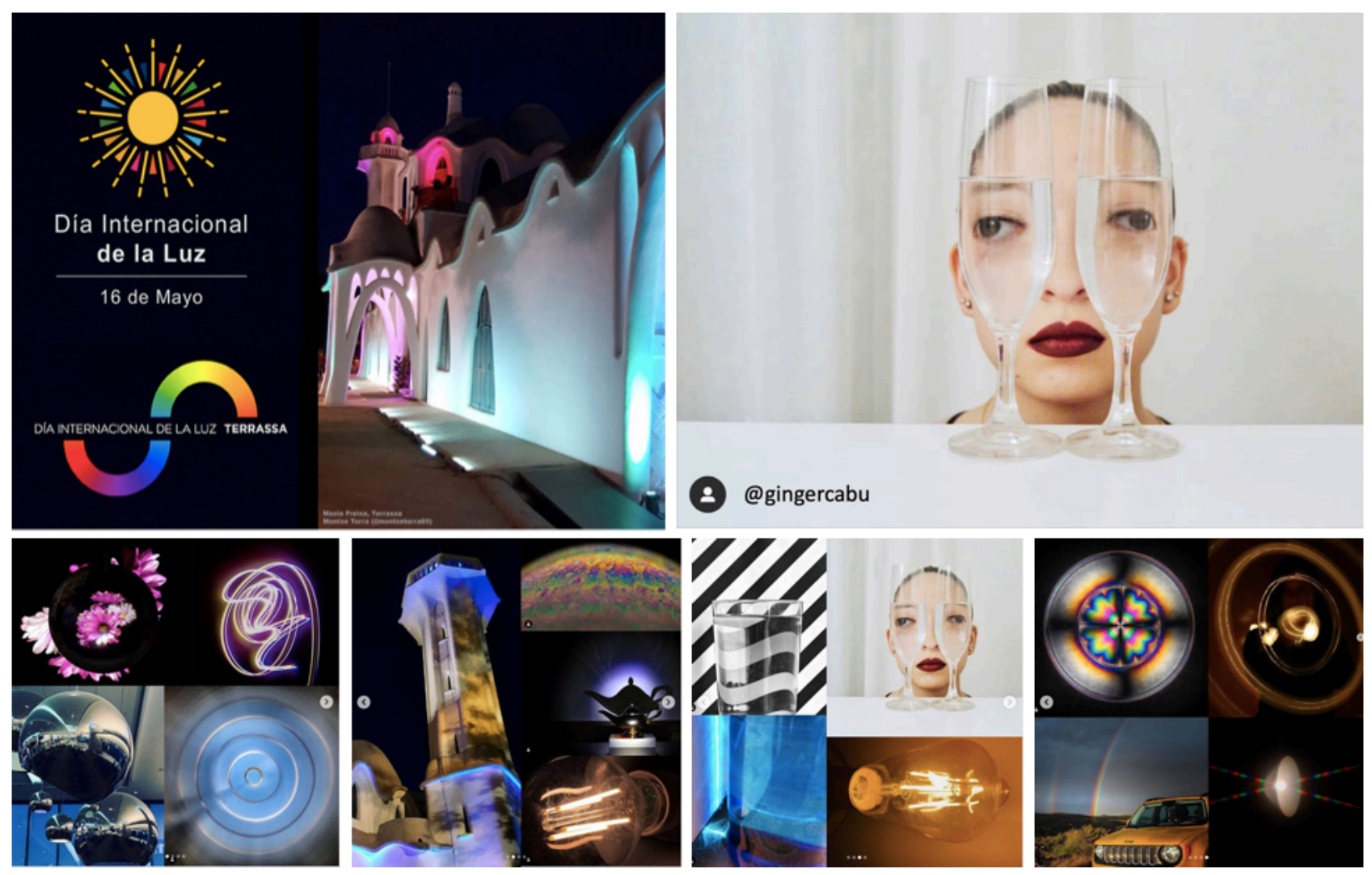

Figure 4. Top-left: Announcement of the 2020 IDL flagship central event in Terrassa; Top-right picture winner of the @DIL20_21Terrassa photo contest. Bottom: some other selected pictures of the photo contest.

\section{OTHER IDL EVENTS IN SPAIN}

As mentioned before, in addition to the central events, the 2018 and 2019 celebrations of the IDL in Spain raised a large number of very interesting activities in many different cities. They have been collected in the webpage [2], but let us remark some of them:

- The exhibition "A Luz e a lente: Historia do microscopio a través da colección Camacho y Pallas" [9], which collects a selection of historical microscope pieces, property of Dr. Tomás Camacho and Dr. Estrella Pallas. Two emblematic pieces of this exhibition are one Leeuwenhoek microscope, built in 1680, and one original edition of the book "Micrographia: or some Physiological Descriptions of Minute Bodies Made by Magnifying Glasses", published by Robert Hooke in 1665 . This exhibition was open in the city of Vigo in 2018, from May $16^{\text {th }}$ until September $23^{\text {th }}$, located at the Museum of Contemporary Art of Vigo.

- The realization of the Fizeau experiment to measure the speed of light. It was reproduced at Santander [10] in 2019 in commemoration of the 200 anniversary of the birth of the French scientist Hyppolite Fizeau. 
- In 2019 COSCE - the Confederation of Scientific Societies of Spain, devoted its annual Workshop of Societies to the Day of Light [11], in collaboration with FACME, the Federation of Spanish Medical Scientific Societies. This event covered different aspects of the interaction of the light with the different sciences. UNED, the Spanish National Distance Education University, recorded a report of this event and was broadcasted in the television chain "La 2 de TVE". This video is based on interviews to different participants and includes, among others, the speakers at the workshop, as well as the President of the Spanish Committee of the International Day of Light.

- The exhibition "GRANAglyphs: A stereoscopic vision of Granada" at the Science Museum (Parque de las Ciencias. Granada) organized by the Optics Department of the University of Granada and the Museum [12].

- The 'Misión ALBA' project [13] for primary school students, an educational project, launched for the first time during the academic year 2018-2019, by the ALBA Synchrotron. The first edition finished in May 2019 and counted with the participation of more than 7,000 students coming from 170 schools all around Spain. It hosts four virtual laboratories under the motto of "making visible the invisible", one of the labs is specially focused on light and its properties.

- The ORIGAMI project [14], that was carried out in the Archaeological Site of the Dolmens of Antequera (Málaga), a site declared by UNESCO World Heritage Site since 2016. Light was used to show the trajectories that mark the exceptionality in the singular orientation of the Dolmens of Antequera, as were imagined by our ancestors about 6,000 years ago. This project was promoted by Victor Marín and the company Brain and Glasses, and it was awarded with a honorable mention 2019 Light Design Awards [15].

- The contest of Micro writings (Microrrelatos) [16] organized by the Faculty of Sciences and Biosciences of Universitat Autònoma de Barcelona (UAB), where professors, students and staff members of the UAB participate writing small writings related to light.

- The PHOTON Awards [17] is an initiative of the Institute of Optics - CSIC which, in collaboration with SEDOPTICA and secpho, aims to recognize the work of communication, dissemination and approach to public opinion of the scientific, technological and social impact of research in optics and photonics and to promote and encourage the teaching of science and research and, in particular, optics and photonics to elementary and high school students. There have been three editions of these awards, 2018, 2019 and 2020.

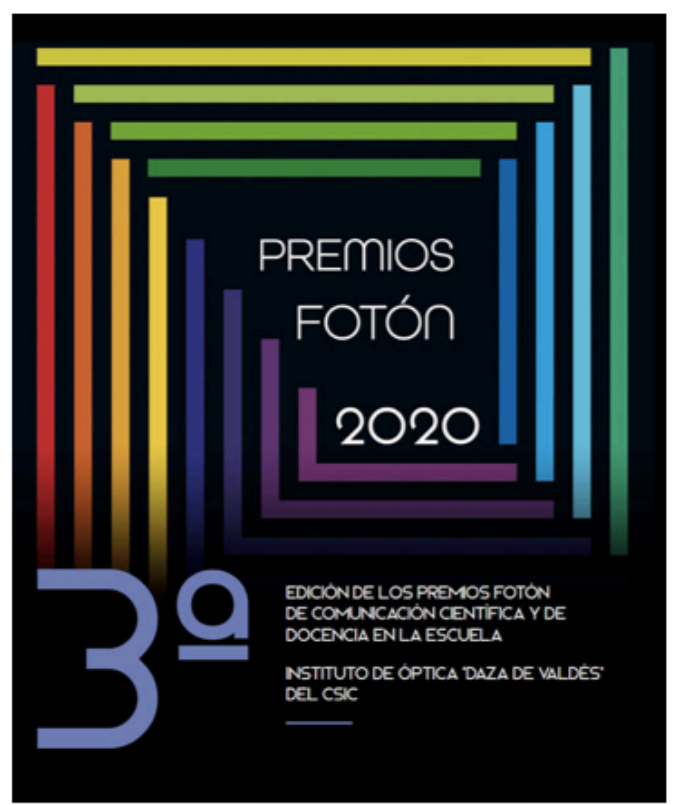

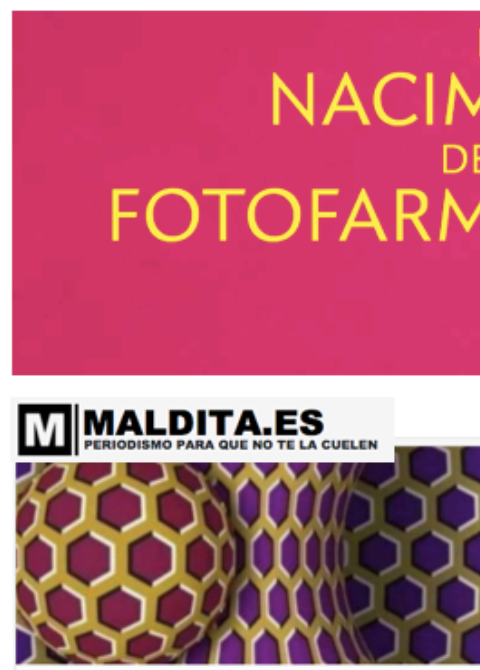

MRLITA CIIMCIM

No, esta ilusión óptica no te dice si estás tranquilo o estresado

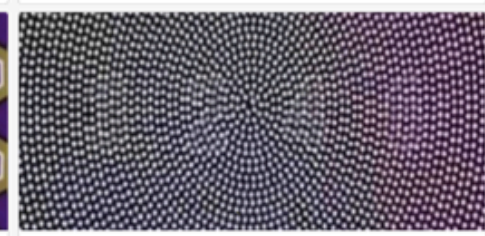

MALOTA CIMCIR

No, esta ilusión óptica no sirve para diagnosticar problemas de visión

Figure 5. Left: Announcement of the 2020 PHOTON Awards by the Institute of Optics-CSIC. Right Top: Detail of the cover page of the publication "The birth of the Photopharmacology", first prize of the 2020 EMITTED PHOTON award. Right bottom: detail of the webpage Maldita Ciencia (https://maldita.es/malditaciencia/), second prize of the 2020 EMITTED PHOTON award. 
The 2020 edition of the PHOTON Awards was completed despite of the restrictions due to the Covid-19 pandemic. The EMITTED PHOTON Award is devoted to recognize and promote the work of scientific communication in the fields of optics and photonics. This year the first prize was awarded to Xavier Rovira Algans, from University of Vic - Central Catalonia University, and Xavier Gómez Santacana, from University of Montpellier, for their article entitled "The birth of the Photo-pharmacology", published in the journal Investigación y Ciencia [18]. The second prize went to the Maldita Ciencia team at the webpage Maldita.es, by Rocío Pérez, Laura García Merino, Clara Jiménez Cruz and Julio Montes, for their work "Maldita Ciencia - Misinformation about optics" [19].

The ABSORBED PHOTON award recognizes educational projects in the field of Optics \& Photonics. This year the winner has been the project entitled "We have no green stars, but we do have a quantum dot television", by Jorge Barrio Gómez de Agüero from the IES Manuel de Falla de Coslada (Madrid). The second prize has been awarded to the activity "Discover the light", presented by Alberto García Mallo and Adela Queimadelos Paramés of the CPR Alborada de Vigo (Pontevedra).

\section{CONCLUSIONS AND PERSPECTIVES}

We continue to promote the IDL activities as a Project related with education and outreach of Optics and Photonics. Many of these activities are oriented to make the society aware of the importance of light-based technologies for the well-being of the humankind. We also promote activities oriented to students in primary and secondary schools in order to attract young talent to the degrees in science and engineering.

The projections of the IDL first two celebrations in Spain allow us to be optimistic about the good continuity of this activity. Unfortunately, the Covid-19 pandemic has forced to cancel almost all the programmed events in 2020. The central event programmed to be held in the city of Terrassa has been postponed to the 2021 celebration.

We are still living uncertain moments, where surely, both the evolution of the pandemic, and the economic situation will affect the IDL activities. However, the academic, research and industrial community related to Optics \& Photonics in Spain is committed with the IDL goals. We all have the important task to be able to align efforts of the different related institutions and companies for the mutual benefit. The IDL represents a unique opportunity and we consider the number of activities and success of participation in the first editions as an excellent sign for the subsequent impact in the next years.

We hope the situation caused by the pandemic can be controlled and the next year we will celebrate 2021 IDL!

Finally, we want to conclude this work by highlighting that two of the four pictures awarded of the SPIE IDL Photo contest were from Spain. Figure 6 shows these two pictures [20]. The picture on the left is credited to the photographer Sergio Ruiz, and it was the winner of the Tech Prize of the 2019 SPIE IDL photo contest. It shows Carlos Escudero working at the CIRCE line of ALBA Synchrotron. The picture on the right is credited to the photographer Julio Castro Pardo, and it is entitled "A dream come true". It was awarded with the $3^{\text {rd }}$ Prize in the 2019 SPIE IDL photo contest.
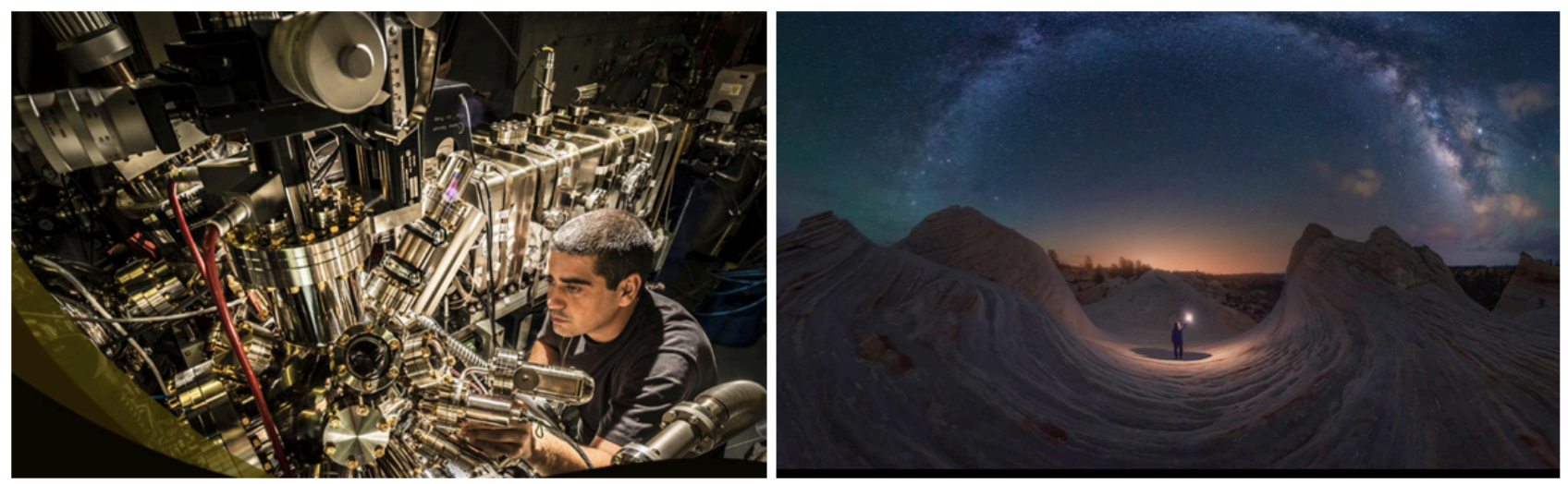

Figure 6. Left: Picture winner of the Tech Prize of the 2019 SPIE IDL photo contest by Sergio Ruiz, showing an image of Carlos Escudero working at the CIRCE line of ALBA Synchrotron. Right: Picture entitled "A dream come true", by Julio Castro Pardo, $3^{\text {rd }}$ Prize in the 2019 SPIE IDL photo contest. 


\section{ACKNOWLEDGEMENTS}

The authors of this paper acknowledge the members of the Spanish Committee of the International Day of Light, and the support of the different organizations and companies that contributed to the IDL in Spain. We also would like to thank Dr. Elisabet Pérez (Chair) and other members of the local organizing Committee of the 2020-21 Central Event of IDL in Spain, to be held in Terrassa.

\section{REFERENCES}

[1] Official international website for the IDL: http://www.lightday.org

[2] Official website in Spain for the IDL: https://www.diadelaluz.es/

[3] Dudley, J., and Rivero González, J., "Día Internacional de la Luz, 16 de mayo: una celebración anual”, Revista Española de Física 32(2), 43-47 (2018). http://revistadefisica.es/index.php/ref/article/view/2437

[4] Yzuel, M.J., and Moreno, I., “16 de mayo, Día Internacional de la Luz”, Opt. Pura Apl. 51(1), i-ii (2018). http://doi.org/10.7149/OPA.51.1.i

[5] Moreno, I., Yzuel, M.J., and Calvo, M.L., "The first International Day of Light in Spain”, Proc. SPIE 10741, Optics Education and Outreach V; 1074109 (2018). https://doi.org/10.1117/12.2320591

[6] Yzuel, M.J., Moreno, I., and Calvo, M.L., "The 2019 International Day of Light in Spain", Opt. Pura Apl. 52(4), xiii-xx (2019). http://dx.doi.org/10.7149/OPA.52.4.xiii

[7] The 2018 Central Event of IDL in Spain at Universidad Complutense de Madrid can be viewed at https://www.youtube.com/watch?v=9pFtjYzjlaQ (morning session) and at https://www.youtube.com/watch?v=PdVIvkKYEaw (afternoon session).

[8] Recording of the conferences of the 2019 Central IDL Event in Spain, Santiago de Compostela. https://www.diadelaluz.es/149-La\%20USCTV\%20graba\%20el\%20Acto\%20Central\%20del $\% 20 \mathrm{D} \% \mathrm{C} 3 \% \mathrm{ADa} \% 20$ Internacional $\% 20 \mathrm{de} \% 201 \mathrm{a} \% 20 \mathrm{Luz} \% 202$ 019

[9] Exhibition "A Luz e a lente: Historia do microscopio a través da colección Camacho y Pallas". https://www.diadelaluz.es/60A \%20Luz $\% 20 \mathrm{e} \% 20 \mathrm{a} \% 20$ lente:\%20Historia\%20do\%20microscopio\%20a $\% 20$ trav $\% \mathrm{C} 3 \% \mathrm{~A} 9 \mathrm{~s} \% 20 \mathrm{da} \% 20$ colecci $\% \mathrm{C} 3 \% \mathrm{~B} 3 \mathrm{n} \% 20 \mathrm{Camacho} \% 20 \mathrm{y} \% 20$ Pallas

[10] Reproduction of the Fizeau experiment: https://www.diadelaluz.es/133Fizeau $\% 20$ y $\% 20$ su $\% 20$ experimento $\% 20 \mathrm{de} \% 201 \mathrm{a} \% 20$ rueda $\% 20$ dentada

[11] COSCE workshop of Societies to the Day of Light: https://www.diadelaluz.es/156La\%20COSCE\%20graba\%20las\%20ponencias\%20de\%20la\%20Jornada\%20de\%20la\%20Luz\%20\%20Jornada\%20de\%20Sociedades\%202019

[12] Exhibition "GRANAglyphs: A stereoscopic vision of Granada": https://diadelaluz.es/157GRANAglifos.\%20Una\%20visión\%20estereoscópica\%20de\%20Granada

[13] Mision ALBA Project. https://www.misionalba.es/es

[14] ORIGAMI Project. https://diadelaluz.es/159-El-proyecto-Origami-usa-luz-1\%C3\%A1ser-para-hacer-visible-elespacio-en-el-Sitio-Arqueol\%C3\%B3gico-de-los-D\%C3\%B3lmenes-de-Antequera

[15] ORIGAMI report on Lighting Design Awards: https://itawards.com/winners/winner.php?id=434\&mode $=\mathrm{hm}$

[16] Universitat Autònoma de Barceloba. Microwriting contest. https://www.uab.cat/web/detall-de-noticia/lerconcurs-de-microrelats-del-dia-internacional-de-la-llum-1345722997310.html?noticiaid=1345786302174

[17] PHOTON Awards, Institute of Optics CSIC. https://www.io.csic.es/premiosfoton/

[18]X. Rovira Algans, and X. Gómez Santacana, "El nacimiento de la fotofarmacología", Investigación y Ciencia, Sept-2019, pp. 30-25 (2019). https://www.investigacionyciencia.es/files/33732.pdf

[19] Maldita Ciencia - La desinformación sobre óptica. https://maldita.es/?s=+\%C3\%B3ptica\&cat=256

[20] SPIE website for the International Day of Light Photo Contest. https://spie.org/about-spie/international-day-oflight/spie-idl-photo-contest 